\title{
PENGARUH FAKTOR FUNDAMENTAL DAN RISIKO SISTEMATIK TERHADAP HARGA SAHAM PERUSAHAAN DI PASAR MODAL SYARIAH (STUDI KASUS DI JAKARTA ISLAMIC INDEX PERIODE 2014-2017)'
}

\author{
Vega Zahrah Narendra Duhita \\ Departemen Ekonomi Syariah-Fakultas Ekonomi dan Bisnis-Universitas Airlangga \\ Email: vega.zahrah.naren-2015@feb.unair.ac.id \\ Nisful Laila \\ Departemen Ekonomi Syariah-Fakultas Ekonomi dan Bisnis-Universitas Airlangga \\ Email: nisful.laila@feb.unair.ac.id
}

\begin{abstract}
:
This research aims to find out and explain the influence of financial fundamental factors (DER, NPM, ROA, TATO, EPS, and PER) and systematic risks (Stock Beta) on stock price of the companies which were registered on Jakarta Islamic Index period 2014-2017. It uses quantitative approach to find out the relation between one variable and another. Data used is a secondary data including the value of every ratio used and closi stock price in ecery company. The object of the research is 16 companies which were registered on Jakarta Islamic Index during the research period. This research focuses on whether the variables used affect companies' stock price by using multiple linier regression test and statistical tool IBM SPSS 25 and determining the level of significance 5\%. The results of the research show that the fundamental factors and systematic risks simultaneously have a positive and significant effect on companies' stock price on JII during period 2014-2017. Meanwhile, the variables of DER, ROA, TATO, EPS partially have a positive and significant effect, the variables of NPM, PER, and stock beta have insignificant effect on companies' stock price on Jll during period 2014-2017.

Keywords: Fundamental Analysis, Stock Price, Systematic Risks, Jakarta Islamic Index.
\end{abstract}

\section{PENDAHULUAN}

Investasi merupakan salah satu

bentuk kegiatan muamalah yang diperbolehkan dan dianjurkan dalam Islam. Kegiatan investasi telah diatur dalam Q.S An-Nisa ayat 9 dimana pada ayat ini menjelaskan tentang investasi yang dapat dilakukan dengan memenuhi beberapa kriteria yang tidak melanggar ketentuan syariah. Investasi terdiri dari beberapa bentuk salah satu diantaranya adalah investasi pada pasar modal. Pasar modal merupakan tempat bagi para investor untuk melakukan traksaksi jual beli saham dengan harapan memperoleh return. Selain itu, pasar modal juga merupakan tempat yang menyediakan informasi perusahaan yang terdaftar di dalamnya. Investor dengan harapannya untuk memperoleh return yang besar seringkali melakukan praktik yang dilarang oleh syariah yaitu praktik spekulasi, riba, gharar, dan maysir. Investasi di pasar modal sering kali dikaitkan dengan kiasan high risk high return dikarenakan risiko dan return dalam teori investasi memiliki hubungan positif dan linier dengan return yang diharapkan. Adapun risiko dalam investasi terdiri dari risiko sistematik dan risiko non sistematik. Sebelum terjun ke dalam pasar modal, investor dianjurkan untuk terlebih dahulu mengetahui dan

1 Jurnal ini merupakan bagian dari skripsi dari Vega Zahrah Narendra Duhita, NIM: 041511433028, yang diuji pada tanggal 24 September 2019. 
Duhita, et al/Jurnal Ekonomi Syariah Teori dan Terapan Vol. 6 No. 10 Oktober 2019: 1984-1994; PENGARUH FAKTOR FUNDAMENTAL DAN RISIKO SISTEMATIK TERHADAP HARGA SAHAM PERUSAHAAN DI PASAR MODAL SYARIAH (STUDI KASUS DI JAKARTA ISLAMIC INDEX PERIODE 2014-2017)

menguasai risiko yang ada agar dapat melakukan transaksi dalam pasar modal secara rasional. Hal-hal yang dapat dilakukan sebelum melakukan kegiatan investasi salah satunya dapat dilakukan dengan cara membandingkan harga saham dengan nilai atau harga yang sebenarnya (fundamental) dari harga saham tersebut. Kegiatan ini dilakukan untuk menilai kewajaran harga suatu saham yang terbentuk di pasar modal. Nilai fundamental dalam suatu saham dapat dilakukan dengan melakukan analisis rasio keuangan masing-masing perusahaan. Adapun analisa secara teknikal dapat dilakukan dengan melalui metode peramalan dengan memperhatikan grafik kecenderungan saham.

Seiring dengan berkembangnya trend investasi di pasar modal pada tahun 2003 PT Bursa Efek Jakarta mendirikan Jakarta Islamic Index (JII) bekerja sama dengan PT Danareksa Invesment Management dengan harapan dapat mendukung transparansi dan akuntabilitas saham berbasis syariah di Indonesia serta memfasilitasi investor yang ingin menanamkan modalnya secara syariah tanpa takut tercampur dengan sesuatu yang berkaitan dengan ribawi. Oleh karena itu, diharapkan para investor yang menanamkan modalnya pada perusahaan yang tergabung dalam Jakarta Islamic Index dapat melakukan keputusan investasinya secara rasional. Keputusan investasi yang rasional dapat dilakukan dengan mendasari keputusan berdasarkan informasi perbandingan harga saham dengan nilai atau harga yang sebenarnya (fundamental) yang dapat diukur dengan menggunakan analisis fundamental dan analisis teknikal.

Berdasarkan latar belakang di atas, maka permasalahan yang akan timbul adalah, "Apakah faktor fundamental (DER, NPM, ROA, TATO, EPS, dan PER) serta risiko sistematik (beta saham) mempengaruhi harga saham perusahaan yang terdaftar di Jakarta Islamic Index baik itu secara bersamasama maupun secara parsial?"

\section{LANDASAN TEORI DAN PENGEMBANGAN HIPOTESIS}

Pasar modal dijabarkan oleh (Tandelilin, 2010) sebagai tempat bertemunya pihak yang memiliki kelebihan dana dengan pihak yang membutuhkan dana, dimana objek yang diperjualbelikan di pasar modal merupakan sekuritas perusahaan. Selain sebagai perantara untuk investor dan perusahaan yang membutuhkan dana, (Hadi, 2013) mengungkapkan pasar modal juga memiliki berbagai peran diantaranya: (1) sumber pembiayaan (jangka panjang) bagi dunia usaha sekaligus memungkinkan alokasi sumber dana secara optimal; (2) alternatif investasi yang memberikan potensi keuntungan dengan resiko yang bisa diperhitungkan melalui keterbukaan, likuiditas, dan diversifikasi investasi; (3) memberikan kesempatan memiliki 
Duhita, et al/Jurnal Ekonomi Syariah Teori dan Terapan Vol. 6 No. 10 Oktober 2019: 1984-1994; PENGARUH FAKTOR FUNDAMENTAL DAN RISIKO SISTEMATIK TERHADAP HARGA SAHAM PERUSAHAAN DI PASAR MODAL SYARIAH (STUDI KASUS DI JAKARTA ISLAMIC INDEX PERIODE 2014-2017)

perusahaan yang sehat dan mempunyai prospek, keterbukaan dan profesionalisme, menciptakan iklim yang berusaha sehat; (4) menciptakan lapangan kerja atau profesi yang menarik; (5) memberikan akses control social; dan (6) menyediakan leading indicator bagi trend ekonomi negara.

Selain pasar modal konvesional, di Indonesia juga terdapat pasar modal syariah dimana menurut (Mardi, 2015) pasar modal syariah merupakan pasar modal yang menerapkan prinsip-prinsip syariah dimana kegiatan investasi di pasar modal syariah terjadi antara shahibul maal dan mudharib dengan mengutamakan kehalalan dan keadilan, secara garis besar prinsip syariah dalam pasar modal diantaranya: (1) pembiayaan maupun investasi hanya dapat dilakukan pada asset atau kegiatan usaha yang halal, spesifik, dan bermanfaat; (2) vang berfungsi sebagai alat bantu pertukaran nilai; (3) akad antara pemilik harta dengan emiten harus jelas; (4) baik pemiliki harta maupun emiten tidak boleh mengambil risiko yang melebihi kemampuannya dan dapat menimbulkan kerugian; (5) menekankan pada mekanisme yang wajar dan prinsip kehati-hatian. Sebagai respin atas kebutuhan informasi tentang investasi syariah, Bursa Efek Jakarta (BEJ) bekerja sama dengan Danareksa Investment Management (DIM) meluncurkan indeks saham syariah yang dikenal sebagai Jakarta Islamic Index pada tanggal 3 Juli
2000. Perbedaan mendasar antara indeks konvesional dan indeks syariah adalah pada indeks konvensional seluruhs aham yang tercatat di bursa masuk ke dalam perhitungan index dengan mengabaikan aspek halal haram asalkan sagam emiten yang terdaftar sudah sesuai dengan aturan yang berlaku. Berbeda dengan JII dimana menurut (Mustafa Edwin Nasution, 2007) penentuan kriteria dari komponen JII disusun berdasarkan persetujuan dari Dewan Pengawas Islam dan PT DIM melalui seleksi yang bersifat normatif dan finansial. Nantinya saham yang terdaftar di Jll akan dikaji ulang setiap enam bulan sekali dengan penentuan komponen indeks pada awal bulan Juli di setiap tahunnya. Apabila terdapat perubahan pada jenis usaha emiten akan selalu diawasi secara terus-menerus berdasarkan data publik yang tersedia.

$$
\text { Investasi yang dilakukan pada }
$$
pasar modal dilakukan dengan tujuan untuk mendapatkan return yang diikuti dengan kemungkinan terjadinya risiko. Risiko dalam investasi terbagi menjadi risiko sistematik dan risiko tidak sistematik. risiko sistematik dihitung dengan menggunakan koefisien beta. Adapun rumus untuk koefisien beta adalah sebagai berikut:

$$
R_{i}=a_{i}+\beta_{i} R_{m}+e_{i}
$$

Keterangan:

$R_{i}=$ Return Sekuritas I (ICMD)

$a=$ Konstanta

$R_{m}=$ Return Indeks Pasar (IHSG)

$B_{i}=$ Beta Sekuritas ke-i 
Duhita, et al/Jurnal Ekonomi Syariah Teori dan Terapan Vol. 6 No. 10 Oktober 2019: 1984-1994; PENGARUH FAKTOR FUNDAMENTAL DAN RISIKO SISTEMATIK TERHADAP HARGA SAHAM PERUSAHAAN DI PASAR MODAL SYARIAH (STUDI KASUS DI JAKARTA ISLAMIC INDEX PERIODE 2014-2017)

$e_{i}=$ Error Term

Untuk mencegah risiko terjadi, salah satu hal yang dapat dilakukan oleh investor dapat memperhatikan harga saham masing-masing perusahaan untuk menilai sebuah perusahaan. Harga Saham menurut (Rusdin, 2008) harga saham ditentukan menurut hukum permintaan-penawaran atau kekuatan tawar-menawar. Makin banyak orang yang ingin membeli saham tertentu, maka harga saham tersebut cenderung naik. Sebaliknya, apabila semakin banyak orang yang ingin menjual suatu saham, maka harga saham tersebut akan cenderung bergerak turun. (Husnan, 1994) mengungkapkan bahwa untuk meramalkan harga saham dapat dilakukan dengan membuat suatu model yang terdiri dari berbagai variabel yang saling berinteraksi sehingga membentuk harga saham. Secara umum, harga saham dapat dinilai dengan melakukan analisis teknikal dan analisis fundamental. Analisis teknikal menggunakan data historis mengenai perkembangan harga saham dan volume perdagangan sebagai elemen utama yang kemudian diolah menjadi grafik. Konsep teknikal beranggapan bahwa pola pergerakan harga saham yang terjadi pada saat ini dan di masa yang lalu cenderung akan terulang kembali di masa yang akan datang. Sedangkan analisis fundamental memberikan perhatian untuk menentukan nilai yang tepat untuk suatu saham. Pengukuran nilai saham secara fundamental dalam penelitian ini dilakukan dengan melakukan analisis DER, NPM, ROA, TATO, EPS, dan PER. Dimana masing-masing pengukuran nilai saham secara fundamental dilakukan bertujuan untuk: (1) DER digunakan untuk mengukur kemampuan perusahaan melunasi kewajibannya; (2) NPM dilakukan untuk mengukur kemampuan perusahaan dalam menghasilkan laba bersih dari penjualan bersih; (3) ROA digunakan untuk mengukur kemampuan perusahaan dalam menghasilkan laba dari aktiva yang digunakan; (4) TATO digunakan untuk mengukur seberapa efisien perusahaan dalam menggunakan asetnya untuk menghasilkan penjualan; (5) EPS digunakan untuk mengetahui laba per saham yang dimiiki oleh perusahaan; dan (6) PER yang digunakan untuk mengukur seberapa besar harga yang ingin dibayar oleh pasar terhadap pendapatan atau laba suatu perusahaan.

Pemilihan faktor di atas sebagai variabel eksogen didasarkan pada pemikiran bahwa faktor tersebut menggambarkan risiko dan return yang akan diterima oleh investor. Pengembangan hipotesis untuk penelitian ini adalah sebagai berikut:

1. Pengaruh Faktor Fundamental dan Beta Saham secara Simultan terhadap Harga Saham

Menurut penelitian yang dilakukan (Astuty, 2017) tentang pengaruh Faktor Fundamental dan Risiko Sistematik 
Duhita, et al/Jurnal Ekonomi Syariah Teori dan Terapan Vol. 6 No. 10 Oktober 2019: 1984-1994; PENGARUH FAKTOR FUNDAMENTAL DAN RISIKO SISTEMATIK TERHADAP HARGA SAHAM PERUSAHAAN DI PASAR MODAL SYARIAH (STUDI KASUS DI JAKARTA ISLAMIC INDEX PERIODE 2014-2017)

terhadap Harga Saham di Bursa Efek Indonesia, hasilnya menunjukkan bahwa PER, EPS, NPM, PBV, dan risiko sistematik (beta saham) berpengaruh secara simultan terhadap harga saham.

H1 : Ada pengaruh Faktor Fundamental dan Beta Saham secara simultan terhadap Harga Saham Perusahaan di JII

2. Pengaruh DER terhadap Harga Saham Menurut penelitian yang dilakukan oleh (Pratama \& Erawati, 2014) tentang Pengaruh CR, DER, ROE, NPM, dan EPS terhadap Harga Saham di Perusahaan Manufaktur yang Terdaftar di BEl periode 2008-2011, hasilnya menunjukkan bahwa DER memiliki pengaruh yang signifikan dan positif terhadap harga saham.

H2 : Ada pengaruh DER terhadap Harga Saham di JII

3. Pengaruh NPM terhadap Harga Saham Menurut penelitian yang dilakukan oleh (Astuty, 2017) tentang Pengaruh Faktor Fundamental dan Risiko Sistematik terhadap Harga Saham di Bursa Efek Indonesia, hasilnya menunjukkan bahwa NPM memiliki pengaruh signifikan terhadap harga saham.

H3 : Ada pengaruh NPM terhadap Harga Saham di JII

4. Pengaruh ROA terhadap Harga Saham Menurut penelitian yang dilakukan oleh (Gursida, 2017) tentang pengaruh faktor fundamental dan makro ekonomi terhadap harga saham, hasilnya menunjukkan bahwa ROA memiliki pengaruh positif dan signifikan terhadap harga saham.

H4 : Ada pengaruh ROA terhadap harga saham

5. Pengaruh TATO terhadap Harga Saham

Menurut penelitian yang dilakukan oleh (Putra, Saryadi, \& Hidayat, 2013) tentang pengaruh kinerja keuangan terhadap harga saham pada perusahaan BUMN (Non-Bank) yang terdaftar di Bursa Efek Indonesia, hasilnya menunjukkan bahwa TATO memiliki pengaruh positif dan signifikan terhadap harga saham.

H5 : Ada pengaruh TATO Terhadap Harga Saham di JII

6. Pengaruh EPS terhadap Harga Saham Menurut penelitian yang dilakukan oleh (Pratama \& Erawati, 2014) dalam penelitiannya menyatakan bahwa EPS memiliki pengaruh positif dan signifikan terhadap harga saham.

H6 : Ada pengaruh EPS terhadap Harga Saham

7. Pengaruh PER terhadap Harga Saham Menurut penelitian yang dilakukan oleh (Azhari, Rahayu, \& Zahroh, Pengaruh ROE, DER, TATO, dan PER terhadap Harga Saham Perusahaan Properti dan Real Estate yang Go Publik di BEl, 2016) tentang pengaruh ROE, DER, TATO, dan PER terhadap Harga Saham Perusahaan Properti dan Real Estate yang Go Publik di Bursa Efek Indonesia menyatakan bahwa PER memiliki 
Duhita, et al/Jurnal Ekonomi Syariah Teori dan Terapan Vol. 6 No. 10 Oktober 2019: 1984-1994; PENGARUH FAKTOR FUNDAMENTAL DAN RISIKO SISTEMATIK TERHADAP HARGA SAHAM PERUSAHAAN DI PASAR MODAL SYARIAH (STUDI KASUS DI JAKARTA ISLAMIC INDEX PERIODE 2014-2017)

pengaruh signifikan terhadap harga saham.

H7 : Ada pengaruh PER terhadap Harga Saham di JII

8. Pengaruh Risiko Sistematik terhadap Harga Saham

Menurut penelitian yang dilakukan oleh (WBBA \& Pratomo, 2013) tentang Analisis Fundamental dan Risiko Sistematik terhadap Harga Saham Perbankan yang Terdaftar pada Indeks LQ45 hasilnya menyatakan bahwa risiko sistematik memiliki pengaruh signifikan terhadap harga saham.

H8 : Ada pengaruh risiko sistematik terhadap Harga Saham di JII

\section{METODE PENELITIAN}

Penelitian ini menggunakan pendekatan penelitian kuantitatif yang dilakukan dengan mengadakan uji hipotesis, pengukuran data, serta penarikan kesimpulan. Variabel yang digunakan dalam penelitian ini terdiri dari variabel eksogen (DER, NPM, ROA, TATO, EPS, PER) dan risiko sistematik serta variabel endogen yaitu harga saham perusahaan di JII periode 2014-2017. Data variabel yang digunakan diperoleh dari laporan proforma keuangan perusahaan yang dipublikasikan melalui website Indonesia Stock Exchange. Pengambilan sampel dilakukan dengan pendekatan puposive sampling dimana sampel yang diambil merupakan perusahaan yang terdaftar di JII dan memiliki laporan keuangan lengkap selama tahun 2014 sampai 2017. Berdasarkan kriteria yang telah ditetapkan berikut adalah perusahaan yang dijadikan sampel dalam penelitian ini:

Tabel 1.

Sampel Penelitian

\begin{tabular}{|c|c|l|}
\hline NO & $\begin{array}{c}\text { KODE } \\
\text { SAHAM }\end{array}$ & \multicolumn{1}{|c|}{ NAMA PERUSAHAAN } \\
\hline 1 & AALI & Astra Agro Lestari Tbk \\
\hline 2 & ADRO & Adaro Energy Tbk \\
\hline 3 & AKRA & AKR Corporindo Tbk \\
\hline 4 & ASII & Astra International Tbk \\
\hline 5 & BSDE & Bumi Serpong Damai Tbk \\
\hline 6 & ICBP & $\begin{array}{l}\text { Indofood CBP Sukses } \\
\text { Makmur Tbk }\end{array}$ \\
\hline 7 & INDF & $\begin{array}{l}\text { Indofood Sukses Makmur } \\
\text { Tbk }\end{array}$ \\
\hline 8 & KLBF & Kalbe Farma Tbk \\
\hline 9 & LPKR & Lippo Karawaci Tbk \\
\hline 10 & LSIP & $\begin{array}{l}\text { PP London Sumatra } \\
\text { Indonesia Tbk }\end{array}$ \\
\hline 11 & PGAS & $\begin{array}{l}\text { Perusahaan Gas Negara } \\
\text { (Persero) Tbk }\end{array}$ \\
\hline 12 & SMRA & Summarecon Agung Tbk \\
\hline 13 & TLKM & $\begin{array}{l}\text { Telekomunikasi Indonesia } \\
\text { (Persero) Tbk }\end{array}$ \\
\hline 14 & UNTR & United Tractors Tbk \\
\hline 15 & UNVR & Unilever Indonesia Tbk \\
\hline 16 & WIKA & $\begin{array}{l}\text { Wijaya Karya (Persero) } \\
\text { Tbk }\end{array}$ \\
\hline
\end{tabular}

Sumber: data diolah penulis, 2019

Analisis yang digunakan dalam penelitian kuantitatif ini adalah dengan menggunakan analisis regresi linier berganda yang dilakukan secara berurutan dimulai dari menghitung besar observasi setiap variabel yang digunakan, kemudian melakukan teknik analisis data dengan bantuan aplikasi statistik IBM SPSS 25, melakukan uji normalitas, melakukan uji asumsi klasik model regresi linier berganda yang meliputi uji multikolinieritas, uji autokorelasi, dan uji heterokedastisitas serta melakukan uji hipotesis yang meliputi uji $t$, uji $f$ dan uji $R$ atau uji koefisien determinasi. 
Duhita, et al/Jurnal Ekonomi Syariah Teori dan Terapan Vol. 6 No. 10 Oktober 2019: 1984-1994; PENGARUH FAKTOR FUNDAMENTAL DAN RISIKO SISTEMATIK TERHADAP HARGA SAHAM PERUSAHAAN DI PASAR MODAL SYARIAH (STUDI KASUS DI JAKARTA ISLAMIC INDEX PERIODE 2014-2017)

Adapun model perhitungan yang digunakan untuk setiap variabel diantaranya:

1. Debt to Equity Ratio

Merupakan perbandingan antara jumlah seluruh utang, termasuk utang lancar dengan seluruh ekuitas yang dimiliki oleh sebuah perusahaan.

2. Net Profit Margin

Merupakan ukuran keuntungan dengan membandingkan antara laba setelah bunga dan pajak dibandingkan dengan penjualan.

3. Return on Asset

Merupakan perbandingan antara laba tahunan sebelum pajak tahun $\dagger$ dengan total aktiva (saldo rata-rata atau akhir) tahun $t$.

4. Total Asset Turn Over

Merupakan perbandingan antara penjualan dnegan total aktiva yang dimiliki oleh perusahaan.

5. Earning Per Share

Merupakan perbandingan antara laba bersih dengan total saham yang dimiliki oleh perusahaan.

6. Price to Earning Ratio

Merupakan perbandingan antara harga saham dengan laba bersih per saham yang dimiliki oleh perusahaan.

7. Risiko Sistematik

Diukur dengan menggunakan koefisien beta. Adapun rumus yang digunakan adalah sebagai berikut:

$$
R_{i}=a_{i}+\beta_{i} R_{m}+e_{i}
$$

\section{HASIL DAN PEMBAHASAN}

Untuk menguji normalitas data dari suatu model regresi dapat dilakukan dengan melihat penyebaran data pada sumbu diagonal. Berdasarkan hasil uji normalitas, sebagaimana terlihat pada gambar grafik 1 di bawah ini, terlihat bahwa titik-titiknya tersebar sepanjang garis diagonal, sehingga dapat disimpulkan bahwa distribusi data dalam penelitian ini telah terdistribusi secara normal.

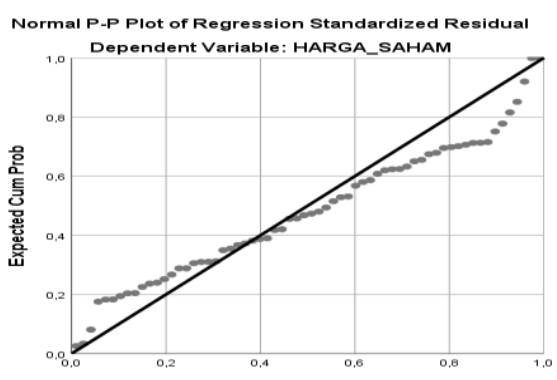

Gambar 1.

\section{Normal Probability Plot of Standardized}

\section{Residual}

Selain melihat pola penyebaran data, uji normalitas dapat dilakukan dengan cara melihat gambar pada grafik histogram. Terlihat pada gambar grafik histogram berikut, pola distribusi yang melenceng ke kanan yang memiliki arti bahwa data dalam penelitian ini telah terdistribusi secara normal.

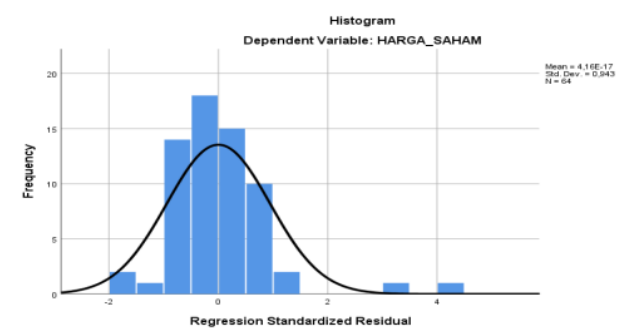

Gambar 2.

\section{Grafik Histogram}


Duhita, et al/Jurnal Ekonomi Syariah Teori dan Terapan Vol. 6 No. 10 Oktober 2019: 1984-1994; PENGARUH FAKTOR FUNDAMENTAL DAN RISIKO SISTEMATIK TERHADAP HARGA SAHAM PERUSAHAAN DI PASAR MODAL SYARIAH (STUDI KASUS DI JAKARTA ISLAMIC INDEX PERIODE 2014-2017)

Selanjutnya, model regresi diuji dengan uji multikolinieritas. Adapun hasil uji multikolinieritas sebagai berikut:

Tabel 2.

Uji Multikolinieritas

\begin{tabular}{|c|c|c|c|}
\hline \multirow{2}{*}{$\begin{array}{l}\text { Varia } \\
\text { bel }\end{array}$} & \multicolumn{2}{|c|}{$\begin{array}{l}\text { Collinearity } \\
\text { Statistics }\end{array}$} & \multirow[t]{2}{*}{ Keterangan } \\
\hline & $\begin{array}{c}\text { Toleran } \\
\text { ce }\end{array}$ & VIF & \\
\hline DER & 0.725 & 1.379 & $\begin{array}{c}\text { Bebas } \\
\text { Multikolinieri } \\
\text { tas }\end{array}$ \\
\hline NPM & 0.349 & 2.869 & $\begin{array}{c}\text { Bebas } \\
\text { Multikolinieri } \\
\text { tas }\end{array}$ \\
\hline ROA & 0.376 & 2.659 & $\begin{array}{c}\text { Bebas } \\
\text { Multikolinieri } \\
\text { tas }\end{array}$ \\
\hline TATO & 0.312 & 3.202 & $\begin{array}{c}\text { Bebas } \\
\text { Multikolinieri } \\
\text { tas }\end{array}$ \\
\hline EPS & 0.798 & 1.253 & $\begin{array}{c}\text { Bebas } \\
\text { Multikolinieri } \\
\text { tas }\end{array}$ \\
\hline PER & 0.842 & 1.187 & $\begin{array}{c}\text { Bebas } \\
\text { Multikolinieri } \\
\text { tas }\end{array}$ \\
\hline $\begin{array}{c}\text { Beta } \\
\text { Saha } \\
\text { m }\end{array}$ & 0.940 & 1.063 & $\begin{array}{c}\text { Bebas } \\
\text { Multikolinieri } \\
\text { tas }\end{array}$ \\
\hline
\end{tabular}

Sumber: data diolah dengan IBM SPSS 25

Dengan hasil yang telah didapatkan maka dapat disimpulkan bahwa seluruh variabel eksogen pada model regresi untuk variabel endogen yang divji dalam penelitian ini tidak terjadi multikolinieritas.

Langkah selanjutnya yang dilakukan untuk menguji model regresi adalah uji autokorelasi, berdasarkan output yang ada, diketahui bahwa tidak terdapat autokorelasi dalam model regresi ini karena nilai hasil perhitungan (4DW) > dari $\mathrm{dU}$ atau 2,262 > 1,8844. kemudian uji heterokedastisitas dilakukan dalam penelitian ini dan hasilnya adalah sebagaimana terlihat pada gambar 3 berikut:

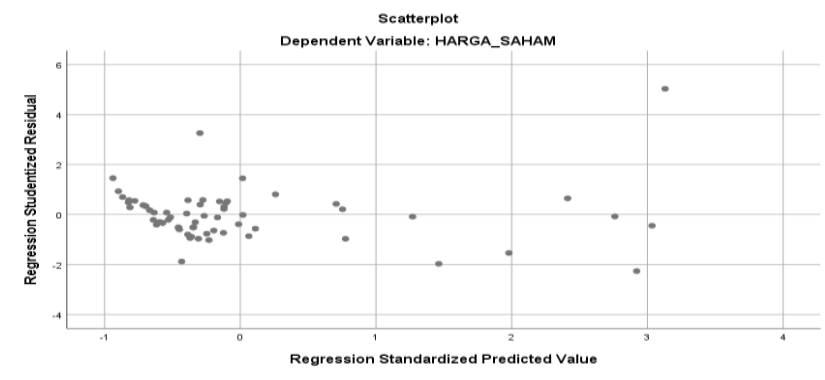

Gambar 3.

\section{Scatterplot}

Dari gambar grafik diatas dapat dilihat bahwa tidak terdapat pola yang jelas, titik-titik data menyebar di atas dan di bawah atau di sekitar angka 0, tidak membentuk gelombang yang melebar kemudian menyempit lalu melebar kembali, dan titik-titik tidak berkumpul hanya di atas maupun di bawah saja sehingga dapat disimpulkan bahwa tidak terjadi gejala heterokedastisitas dalam model regresi ini.

Adapun berdasarkan hasil perhitungan regresi linier berganda didapatkan hasil persamaan regresi linier sebagai berikut:

$$
\begin{aligned}
Y=-8182,709 & +2969,349 X_{1}-237,104 X_{2} \\
& +766,203 X_{3}+1376,044 X_{4} \\
& +16,848 X_{5}+2,080 X_{6} \\
& +2440,284_{X 7}
\end{aligned}
$$

Tabel 3.

Hasil Perhitungan Analisis Regresi Linier Berganda

\begin{tabular}{|c|c|c|c|}
\hline \multirow{2}{*}{ Variabel } & \multicolumn{2}{|c|}{ Model Regresi } & Uji F \\
\cline { 2 - 3 } & Koefisien & $\mathrm{T}$ & $\mathrm{F}$ \\
\hline (Constant) & $-8182,709$ & $-5,565$ & \multirow{2}{*}{} \\
\hline DER & 2969,349 & 3,652 & \\
\hline
\end{tabular}


Duhita, et al/Jurnal Ekonomi Syariah Teori dan Terapan Vol. 6 No. 10 Oktober 2019: 1984-1994; PENGARUH FAKTOR FUNDAMENTAL DAN RISIKO SISTEMATIK TERHADAP HARGA SAHAM PERUSAHAAN DI PASAR MODAL SYARIAH (STUDI KASUS DI JAKARTA ISLAMIC INDEX PERIODE 2014-2017)

\begin{tabular}{|c|c|c|c|}
\hline NPM & $-237,104$ & $-3,658$ & \\
\cline { 1 - 3 } ROA & 766,203 & 9,210 & \multirow{2}{*}{86,522} \\
\cline { 1 - 3 } TATO & 1376,044 & 2,416 & \\
\hline EPS & 16,848 & 14,621 & \\
\hline PER & 2,080 & 0,140 & \\
\cline { 1 - 3 } BETA_SAHAM & 2440,284 & 0,709 & \\
\cline { 1 - 2 } R Square & \multicolumn{2}{|c|}{0,915} & \\
\hline
\end{tabular}

Sumber: Hasil Uji IBM SPSS 25

Berdasarkan tabel 3 diatas dapat diketahui dari uji T bahwa secara parsial variabel DER, ROA, TATO, dan EPS memiliki pengaruh positif dan signifikan terhadap harga saham perusahaan di Jll selama periode 2014-2017, sedangkan variabel NPM, PER, dan Beta Saham tidak memiliki pengaruh signifikan terhadap harga saham perusahaan di Jll selama periode 2014-2017. Adapun hasil uji $F$ untuk penelitian ini ditemukan bahwa secara bersama-sama faktor fundamental (DER, NPM, ROA, TATO, EPS, dan PER) serta beta saham berpengaruh signifikan terhadap harga saham perusahaan di Jll periode 2014-2017. Kemudian dari hasil analisa pada tabel 3 dapat diketahui nilai $R^{2}=$ 0,915, hal ini menunjukkan bahwa harga saham perusahaan di JII periode 2-142017 dipengaruhi oleh DER, NPM, ROA, EPS, PER, dan beta saham sebesar 91,5\%, sedangkan sisanya sebesar $8,5 \%$ dipengaruhi oleh faktor lain di luar model regresi ini.

\section{v. SIMPULAN}

1. Secara simultan faktor fundamental kevangan (DER, NPM, ROA, TATO, EPS, dan PER) serta risiko sistematik berpengaruh secara positif dan

signifikan terhadap harga saham perusahaan yang terdaftar di JII periode 2014-2017 dan dapat disimpulkan $\mathrm{H} 1$ diterima.

2. DER memiliki pengaruh positif dan signifikan terhadap harga saham perusahaan di JII periode 2014-2017 dan dapat disimpulkan bahwa $\mathrm{H} 2$ diterima.

3. NPM tidak berpengaruh secara signifikan terhadap harga saham perusahaan di JII periode 2014-2017 dan dapat disimpulkan bahwa H3 ditolak.

4. ROA memiliki pengaruh positif dan signifikan terhadap harga saham perusahaan di Jll periode 2014-2017 dan dapat disimpulkan bahwa $\mathrm{H} 4$ diterima.

5. TATO memiliki pengaruh positif dan signifikan terhadap harga saham perusahaan di Jll periode 2014-2017 dan dapat disimpulkan bahwa H5 diterima.

6. EPS memiliki pengaruh positif dan signifikan terhadap harga saham perusahaan di Jll periode 2014-2017 dan dapat disimpulkan bahwa $\mathrm{H} 6$ diterima.

7. PER tidak berpengaruh secara signifikan terhadap harga saham perusahaan di JII periode 2014-2017 dan dapat disimpulkan bahwa $\mathrm{H7}$ ditolak.

8. Risiko Sistematik (beta saham) tidak berpengaruh secara signifikan terhadap harga saham perusahaan di 
Duhita, et al/Jurnal Ekonomi Syariah Teori dan Terapan Vol. 6 No. 10 Oktober 2019: 1984-1994; PENGARUH FAKTOR FUNDAMENTAL DAN RISIKO SISTEMATIK TERHADAP HARGA SAHAM PERUSAHAAN DI PASAR MODAL SYARIAH (STUDI KASUS DI JAKARTA ISLAMIC INDEX PERIODE 2014-2017)

JII periode 2014-2017 dan dapat disimpulkan $\mathrm{H} 8$ ditolak.

\section{DAFTAR PUSTAKA}

A.Hasthoro, H., \& Jepriyanto, E. (2011). Pengaruh Faktor-Faktor Fundamental Keuangan dan Risiko Sistematik terhadap Harga Saham Perusahaan yang Tergabung dalam Jakarta Islamic Index (JII). EFEKTIF: Jurnal Bisnis dan Ekonomi , 17-30.

Al-Qur'an dan Hadits.

Anastasia, N., Gunawan, Y. W., \& Wijiyanti, I. (2003). Analisis Faktor Fundamental dan Risiko Sistematik terhadap Harga Saham Properti di BEJ. Jurnal Akuntansi \& Keuangan , 123-132.

Anshori, M. (2009). Metodologi Penelitian Kuantitatif. Surabaya: Airlangga University Press.

Arifin, A. (2002). Membaca Saham. Yogyakarta: Andi.

Astuti, D. (2004). Manajemen Keuangan Perusahaan. Jakarta: Ghalia Indonesia.

Astutik, D. E., Surachman, \& Djazuli, A. (2014). The Effect of Fundamental and Technical Variables on Stock Price (Study on Manufacturing Companies Listed in Indonesia Stock Exchange). Journal of Economics, Business, and Accountancy Ventura , 345-352.

Astuty, P. (2017). The Influence of Fundamental Factors and Systematic Risk to Stock Prices on
Companies Listed in the Indonesian Stock Exchange. European Researches Studies Journal , 230240.

Azhari, D. F., Rahayu, S. M., \& Z.A, Z. (2016). Pengaruh ROE, DER, TATO dan PER terhadap Harga Saham Perusahaan Properti dan Real Estate yang Go Public di Bursa Efek Indonesia. Jurnal Administrasi Bisnis

Azhari, D. F., Rahayu, S. M., \& Zahroh, Z. (2016). Pengaruh ROE, DER, TATO, dan PER terhadap Harga Saham Perusahaan Properti dan Real Estate yang Go Publik di BEI. Jurnal Administrasi Bisnis , 1-5.

Badruzaman, J. (2017). Pengaruh Earning Per Share terhadpa Harga Saham. Jurnal Akuntansi, Online.

Balan, A., \& Lal K.M, A. (2016). Impact of Fundamental Factors on Stock Prices with Special Preferance to Automobile Sector in India. IJARIIE , 26-31.

Elsanti, Y. U., Lukiastuti, F., \& Pantawis, S. (2014). Pengaruh Faktor Fundamental dan Risiko Sistematik terhadap Harga Saham Sektor Properti di Bursa Efek Indonesia Tahun 2008-2012. Maksimum Vol. 4 No.2 , 38-47.

Fakhruddin, D. T. (2001). Pasar Modal di Indonesia. Jakarta: Salemba Empat.

Ghozali, I. (2001). Aplikasi Analisis Multivariate dengan Program SPSS. 
Duhita, et al/Jurnal Ekonomi Syariah Teori dan Terapan Vol. 6 No. 10 Oktober 2019: 1984-1994; PENGARUH FAKTOR FUNDAMENTAL DAN RISIKO SISTEMATIK TERHADAP HARGA SAHAM PERUSAHAAN DI PASAR MODAL SYARIAH (STUDI KASUS DI JAKARTA ISLAMIC INDEX PERIODE 2014-2017)

Semarang: Badan Penerbit

Universitas Diponegoro.

Ghozali, I. (2007). Aplikasi Analisis Multivariate dengan Program SPSS.
Semarang: Badan Penerbit Universitas Diponegoro.

Gitman, L. J. (2005). Fundamental of Investing. Pearson. 